\title{
T-cell-derived cytokines, nitric oxide production by peripheral blood monocytes and seric anti-Leishmania (Leishmania) chagasi IgG subclass patterns following immunization against canine visceral leishmaniasis using Leishvaccine and Leishmune ${ }^{\circledR}$
}

\author{
Márcio Sobreira Silva Araújo ${ }^{\mathrm{a}, \mathrm{b}}$, Renata Aline de Andrade ${ }^{\mathrm{a}}$, Renato Sathler-Avelar ${ }^{\mathrm{a}}$, \\ Andréa Teixeira-Carvalho ${ }^{a}$, Mariléia Chaves Andrade ${ }^{a}$, Leonardo Rocha Vianna ${ }^{c}$, \\ Wilson Mayrink ${ }^{\mathrm{b}}$, Alexandre Barbosa Reis ${ }^{\mathrm{d}}$, Luiz Cosme Cotta Malaquias ${ }^{\mathrm{e}, \mathrm{f}}$, \\ Maria Norma Mello ${ }^{\mathrm{b}}$, Olindo Assis Martins-Filho ${ }^{\mathrm{a}, *}$
}

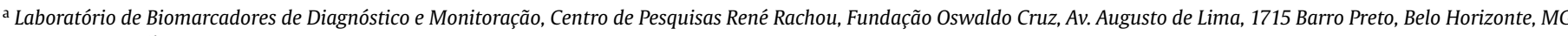
30190-002, Brazil

${ }^{\mathrm{b}}$ Departamento de Parasitologia, Instituto de Ciências Biológicas, Universidade Federal de Minas Gerais, Avenida Antônio Carlos, 6627, Belo Horizonte, MG 31270-901, Brazil

c $4^{\circ}$ Cia da Polícia Militar de Minas Gerais - PMMG, Rua Padre Feijó, 917, Belo Horizonte, MG 30285-350, Brazil

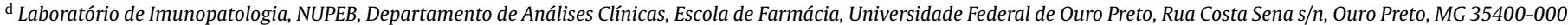
Brazil

e Faculdade de Ciências da Saúde, Universidade Vale do Rio Doce, Rua Israel Pinheiro no. 2000 - Bloco 13, Campus Universitário - Governador Valadares, MG 35020-220, Brazil

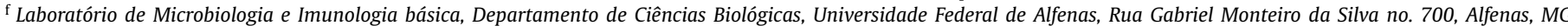
37130-000, Brazil

\section{A R T I C L E I N F O}

\section{Article history:}

Received 6 October 2008

Received in revised form

26 November 2008

Accepted 28 November 2008

Available online 25 December 2008

\section{Keywords:}

Canine visceral leishmaniasis

Leishvaccine

Leishmune $^{\circledR}$

Cytokines

Nitric oxide

IgG subclasses

\begin{abstract}
A B S T R A C T
It is generally accepted that distinct cytokine expression by the cellular immune response plays a critical role during the outcome of experimental as well as natural canine visceral Leishmaniasis (CVL). Despite the fact that immunoprophylaxis of CVL has become an important control strategy and protective immunity has been reported upon immunization with whole as well as purified Leishmania antigens, the cytokine profile of T-cells triggered by anti-CVL vaccines still remain to be determined. Herein, we have developed a cross-sectional analysis of German Shepherd dogs submitted to vaccination protocols with Leishvaccine $(n=6)$ and Leishmune ${ }^{\circledR}(n=6)$. Our data identified distinct immunological profiles elicited by Leishvaccine and Leishmune ${ }^{\circledR}$, with the Leishvaccine triggering a mixed, IFN- $\gamma$ and IL-4, cytokine pattern in addition to high levels of anti-Leishmania IgG1, whereas the Leishmune ${ }^{\circledR}$ induced an immunological pattern characterized by enhanced levels of IFN- $\gamma$, NO and anti-Leishmania chagasi IgG2. It was important to notice that despite the distinct immunological patterns triggered by Leishvaccine and Leishmune ${ }^{\circledR}$, the ability of both immunobiologicals to activate T-cell-derived IFN- $\gamma$ synthesis further suggesting their immunogenic potential against CVL. These findings added support to our hypothesis that both antigenic composition (whole antigen in Leishvaccine versus purified antigen in Leishmune ${ }^{\circledR}$ ) as well as the adjuvant nature (BGC and saponin) used for the vaccine formulation may count for the distinct activation pattern observed.
\end{abstract}

(C) 2008 Elsevier Ltd. All rights reserved.

\section{Introduction}

Visceral leishmaniasis (VL) affects 500,000 people worldwide with a dramatic increase in the number of reported cases during the last few years [1-3]. This disease is considered as a zoonoses or antroponoses, depending on the studied region. In Brazil, likewise in the New World and in the Mediterranean area, VL is a

\footnotetext{
* Corresponding author. Tel.: +55 313349 7764; fax: +55 3132953115

E-mail address: oamfilho@cpqrr.fiocruz.br(O.A. Martins-Filho).
}

canidae zoonoses and therefore the current strategy for managing the disease control is based on three major actions, including (1) the systematic treatment of human cases, (2) vector control and (3) the elimination of seropositive dogs [4]. The establishment of immunoprophylactic tools to control the canine visceral leishmaniasis (CVL) represent an important issue to upgrade the strategy for managing the leishmaniasis control $[5,6]$. In this context, considerable effort has been dedicated in the development of vaccines against CVL, able to modify the immune repertoire and advances have been already reported [7]. Several promising vaccine have been proposed as anti-CVL vaccines and include live/killed Leish- 
mania parasites (first-generation), purified Leishmania antigens or live recombinant bacteria expressing Leishmania antigens (second generation) as well as antigen-encoding DNA plasmids (third generations) [8-11].

Recently, the Leishmune ${ }^{\circledR}$, the pioneer second generation vaccine, composed of purified fraction named fucose mannose ligand (FML) isolated from Leishmania donovani promastigotes plus saponin as adjuvant, have been licensed in Brazil and become commercially available [8-11]. It is important to mention that the Leishmune ${ }^{\circledR}$ is the only anti-CVL vaccine registered in the world, currently in use in Brazil, with protective potential supported by the literature $[8,10]$. This formulation proved to be safe, protective and highly immunogenic for dogs [8-13] as well as able to the block CVL transmission [14].

It is a generally accepted that a protective vaccine against Leishmania infection should be able to trigger a specific cellular immune response, besides a type- 1 cytokine pattern, which may plays a critical role in resistance to the disease onset [15]. In the murine model for Leishmania infection, IFN- $\gamma$ and IL- 4 has been already reported as important hallmarks of these two poles of immune response, as they are associated with protection and susceptibility to Leishmania infection, respectively [16-18]. In CVL, although the general cytokine expression during the outcome of experimental infection has been already reported [19-22], little is known about the cellular immune response triggered by immunoprotective vaccines [23], especially regarding the Leishvaccine and Leishmune ${ }^{\circledR}$. Recently, we have demonstrated that Leishvaccine and Leishmune ${ }^{\circledR}$ elicited distinct profiles of innate and adaptive immune response [24]. While Leishvaccine promoted an early recruitment of neutrophils and eosinophils with late involvement of monocytes, Leishmune ${ }^{\circledR}$ induced early and persistent recruitment of neutrophils and monocytes, without the enrollment of eosinophils. Regarding the adaptive immunity, Leishvaccine sponsored a mixed profile, associated with phenotypic changes in both $\mathrm{CD} 4^{+}$and $\mathrm{CD}^{+}$ T-lymphocytes as well as on B-cells. In contrast, Leishmune ${ }^{\circledR}$ was associated with phenotypic changes in T-lymphocytes, particularly in $\mathrm{CD}^{+} \mathrm{T}$-cells. We have then hypothesized that the ability of both immunobiologicals to enroll macrophages and $\mathrm{CD}^{+} \mathrm{T}-$ cells could be considered priority vaccines with a high-quality immunogenic potential against CVL [24]. Aiming to further focus on the immune response triggered by Leishvaccine and Leishmune ${ }^{\circledR}$ herein, we have further characterized the cellular and humoral immune response of dogs submitted to vaccination protocols with Leishvaccine and Leishmune ${ }^{\circledR}$. The main goal of the current work was to investigate, in a cross-sectional study, the cytokine profile of circulating T-cell subsets, besides the level of nitric oxide synthesis by peripheral blood monocytes as well as the anti-Leishmania IgG subclass patterns after Leishvaccine and Leishmune ${ }^{\circledR}$ vaccination.

\section{Materials and methods}

\subsection{Animals, vaccination protocols and blood sampling}

Twelve healthy German Shepherd dogs, 8 males and 4 females, age ranging from 18 to 60 months old, maintained at the kennel of Polícia Militar de Minas Gerais, Brazil during the entire experimental procedures, were included in this investigation. The dogs included in this study were selected based on their negative serological results in the enzyme-linked immunosorbent assay (ELISA, Biomanguinhos, FIOCRUZ, RJ, Brazil) used as a 'reference standard' test for the diagnosis of CVL. All animals were treated for intestinal helminthic infections and immunized against parvovirosis, leptospirosis, distemper, parainfluenza and hepatitis and maintained in quarantine prior their inclusion in the study. During the entire experimental procedures, the animals received drinking water and a balanced feed given ad libitum.
The selected dogs were divided into three groups named: Group 1: "Unvaccinated" dogs, Group 2: "Leishvaccine" immunized dogs and Group 3: "Leishmune ${ }^{\circledR}$ " vaccinated dogs. The group "Unvaccinated" consisted of 8 animals, 4 males and 4 females (Dog\#1, Dog\#2, Dog\#3, Dog\#4, Dog\#5, Dog\#6, Dog\#7 and Dog\#8). The group "Leishvaccine" was consisted of 6 animals, 4 males and 2 females, 4 of them also evaluated before vaccination (Dog\#1, Dog\#2, Dog\#3, Dog\#4) and 2 evaluated only after vaccination (Dog\#9 and Dog\#10). The group "Leishmune ${ }^{{ }^{\circledR \prime}}$ was consisted of 6 animals, 4 males and 2 females, 4 of them also evaluated before vaccination (Dog\#5, Dog\#6, Dog\#7, Dog\#8) and 2 evaluated only after vaccination (Dog\#11 and Dog\#12).

Dogs in the Leishvaccine group were immunized throughout a complete vaccination regimen that included three subcutaneous doses of the vaccine with an interval of 21 days between each. Leishvaccine was prepared likewise described by Mayrink et al. [25], but consisted of Leishmania (Leishmania) amazonensis (strain IFLA/BR/1967/PH8) antigenic preparation using non-live lyophilized Bacille Calmette-Guérin, BCG (Fundação Ataulfo de Paiva, RJ, Brazil) as adjuvant. The first dose corresponded to $0.6 \mathrm{ml}$ of Leishvaccine $(360 \mu \mathrm{g}$ of protein) plus $0.4 \mathrm{ml}$ of physiologic saline ( $\mathrm{NaCl} 0.9 \%$ in distilled water) containing $400 \mu \mathrm{g}$ of BGC dry-weight as adjuvant. The second dose corresponded to $0.6 \mathrm{ml}$ of Leishvaccine ( $360 \mu \mathrm{g}$ of protein) plus $0.3 \mathrm{ml}$ of physiologic saline $(\mathrm{NaCl} 0.9 \%$ in distilled water) containing $300 \mu \mathrm{g}$ of BGC dry-weight as adjuvant. The third dose corresponded to $0.6 \mathrm{ml}$ of Leishvaccine ( $360 \mu \mathrm{g}$ of protein) plus $0.2 \mathrm{ml}$ of physiologic saline ( $\mathrm{NaCl} 0.9 \%$ in distilled water) containing $200 \mu \mathrm{g}$ of BGC dry-weight. Dogs in the Leishmune ${ }^{\circledR}$ group were submitted to a complete vaccination regimen as recommended by the manufacturer (FortDodge ${ }^{\circledR}$, Campinas, SP, Brazil), which included three subcutaneous doses of $1.0 \mathrm{ml}$ of vaccine with an interval of 21 days between each dose. Leishmune ${ }^{\circledR}$ is composed of $1.5 \mathrm{mg}$ lyophilized FML antigen plus $0.5 \mathrm{mg}$ of Quillaja saponaria saponins (QS21 and deacylated) of Riedel de Haen reconstituted in $1 \mathrm{ml} \mathrm{NaCl}$ $0.9 \%$ sterile saline solution and administered subcutaneously. The FML-vaccine, Leishmune ${ }^{\circledR}$, is registered as a Patent: INPI number: PI1100173-9 (18.3.97), Federal University of Rio de Janeiro, Brazil.

Peripheral blood samples were collected from the radial vein into two vacutainer tubes, one containing sodium heparin and another one without any anticoagulant (BD Pharmingen, San Diego, CA, USA). The whole blood and sera samples were collected from unvaccinated dogs and also 40 days after the last immunization dose of dogs submitted to vaccination protocols with Leishvaccine and Leishmune ${ }^{\circledR}$. Whole blood samples were maintained at room temperature until processing. The sera samples were stored at $-20^{\circ} \mathrm{C}$ and thawed immediately before the flow immunoflurometric analysis of anti-Leishmania chagasi antibodies.

All procedures in this study were according to the guidelines set by the Brazilian Animal Experimental College (COBEA). This study was approved by the Ethical Committee for the use of Experimental Animals of the Universidade Federal de Minas Gerais, Brazil (CETEA).

\subsection{Preparation of soluble L. chagasi antigen and fixed L. chagasi promastigotes forms}

L. chagasi promastigote forms (MHOM/BR/1972/BH46) were grown in liver infusion tryptose medium (LIT), supplemented with $10 \%$ of fetal bovine serum (FBS) [26] at $24{ }^{\circ} \mathrm{C}$ temperature. Stationary-phase parasites ( 8 days of growth) were transferred to $50 \mathrm{ml}$ polypropylene tubes (Falcon, Becton Dickinson, San Diego) and submitted to differential centrifugation $(100 \times \mathrm{g}, 10 \mathrm{~min}$, room temperature) to remove remaining clusters of parasites contaminants in the pellet. Prior to recover the single-cell parasite 
suspension, the supernatant was left to rest for $10 \mathrm{~min}$ at room temperature. The supernatant consisting of single-cell parasite suspension was transferred to another $50 \mathrm{ml}$ polypropylene tube and spin down at high speed $(1000 \times g)$ for $10 \mathrm{~min}$ at $4-8^{\circ} \mathrm{C}$. The supernatant was discarded and the pellet washed twice $(1000 \times \mathrm{g}, 10 \mathrm{~min}$, $\left.4-8{ }^{\circ} \mathrm{C}\right)$ with phosphate buffered saline, PBS (0.15 M, pH 7.2). After the wash steps, the single-cell $L$. chagasi promastigote suspension was then used in the preparation of soluble L. chagasi antigen or fixed suspension of $L$. chagasi promastigote.

The soluble $L$. chagasi antigen was prepared from the frozen $\left(-70^{\circ} \mathrm{C}\right)$ dry pellet obtained from the $L$. chagasi single-cell promastigote suspension. The frozen pellet was thawed, resuspended into equal volume of cold PBS and submitted to three ultra-sound cycles of 1 min at $40 \mathrm{~W}$ on ice bath (Sonifier Cell Disruptor ${ }^{\circledR}$ - Branson Sonic Power Co., EUA). The sonicated material was centrifuged at $50,000 \times \mathrm{g}$ for $1 \mathrm{~h}$ and $30 \mathrm{~min}$ at $4{ }^{\circ} \mathrm{C}$. The supernatant was transferred to dialysis tubes and dialyzed through PBS for $24 \mathrm{~h}$, and submitted to three PBS changes every $6 \mathrm{~h}$. The dialyzed soluble antigen was filtered in $0.22 \mu \mathrm{m}$ disposable syringe sterile filters of under aseptic conditions. One aliquot was taken for protein quantification by the method described by Lowry et al. [27]. Final protein concentration was adjusted to $1000 \mu \mathrm{g} / \mathrm{ml}$. Antigen preparation was stored in $100 \mu \mathrm{l}$ aliquots at $-70^{\circ} \mathrm{C}$ prior the use in the in vitro cultures of peripheral blood mononuclear cells.

The suspension of fixed $L$. chagasi promastigotes were prepared by resuspending the dry pellet obtained from the L. chagasi singlecell promastigote suspension in five times higher volume of fix solution consisting of equal volume of cold PBS plus FACS FIX solution ( $10 \mathrm{~g} / \mathrm{l}$ paraformaldehyde, $10.2 \mathrm{~g} / \mathrm{l}$ sodium cacodilate, $6.63 \mathrm{~g} / \mathrm{l}$ sodium chloride, pH 7.2, all from Sigma, St. Louis, MO, USA). Following overnight incubation at $4{ }^{\circ} \mathrm{C}$, the fixed promastigotes were washed once in PBS, counted in Neubauer chamber and stored at $4{ }^{\circ} \mathrm{C}$. The suspension adjusted to $1.0 \times 10^{7}$ promastigotes $/ \mathrm{ml}$ in PBS $3 \%$ FBS prior use in the flow cytometric analysis of anti-fixed $L$. chagasi promastigotes antibodies by flow cytometry-FC-AFPA.

\subsection{Isolation and in vitro culture of peripheral blood mononuclear cells}

Peripheral blood mononuclear cells (PBMC) were isolated from heparinized blood samples previously diluted in equal volume of RPMI 1640 (Gibco, Grand Island, NY, USA) that had been layered onto $15 \mathrm{ml}$ of Ficoll-Hypaque density gradient (Histopaque ${ }^{\circledR}$ 1.077; Sigma Chemical Co.) and centrifuged at $700 \times g$ for $40 \mathrm{~min}$ at room temperature. The PBMC cushion was collected in the interface between the top plasma layer and the Ficoll-Hypaque column. Cells were then washed twice with RPMI $1640(600 \times$ g, for $10 \mathrm{~min}$, at room temperature), counted and resuspended in RPMI 1640 at $1 \times 10^{7}$ cells $/ \mathrm{ml}$.

The culture assays were performed in 24-well flat-bottomed tissue culture plates (Corning, New York, NY, USA), each well containing $800 \mu \mathrm{l}$ of cell culture medium comprising of RPMI 1640 supplemented with streptomycin $(100 \mathrm{mg} / \mathrm{ml})$, penicillin $(100 \mathrm{U} / \mathrm{ml})$, L-glutamine $(2 \mathrm{mM}), \beta$-mercaptoethanol $\left(5 \times 10^{-5} \mathrm{M}\right)$ and $10 \%$ FBS. Aliquots of $100 \mu$ of the PBMC suspension $\left(1 \times 10^{6}\right.$ cells/well) were added to quadruplicate wells following the addition of $100 \mu$ l of RPMI 1640 (control cultures, CC) or $100 \mu \mathrm{l}$ of soluble $L$. chagasi antigen (SLA) at final concentration of $25 \mu \mathrm{g} / \mathrm{ml}$ (stimulated cultures, SLA). Cultures were submitted to incubation in $5 \% \mathrm{CO}_{2}$ humidified incubator, at $37^{\circ} \mathrm{C}$, for 5 days. Brefeldin $\mathrm{A}, \mathrm{BFA}$ (Sigma, St. Louis, MO. USA) was added to each well at final concentration of $10 \mu \mathrm{g} / \mathrm{ml}$ and cultures submitted to an additional period of $4 \mathrm{~h}$ of incubation in $5 \% \mathrm{CO}_{2}$ humidified incubator, at $37^{\circ} \mathrm{C}$.

Short-term whole blood cultures were performed to evaluate the assay and sample viability (positive control cultures, PMA -Phorbol 12-Myristate 13-Acetate). For this purpose, a $500 \mu \mathrm{l}$ aliquot of whole blood was incubated in the presence of $500 \mu \mathrm{l}$ of RPMI-1640 plus PMA (Sigma, St. Louis, MO, USA) at a final concentration of $25 \mathrm{ng} / \mathrm{ml}$, ionomycin (Sigma, St. Louis, MO, USA) at $1 \mu \mathrm{g} / \mathrm{ml}$ and BFA at final concentration of $10 \mu \mathrm{g} / \mathrm{ml}$. The positive control culture was maintained for $4 \mathrm{~h}$ in $5 \% \mathrm{CO}_{2}$ humidified incubator at $37^{\circ} \mathrm{C}$. At the end of incubation periods, all cultures were treated with EDTA diluted in PBS (Sigma, St. Louis, MO, USA) at a final concentration of $2 \mathrm{mM}$ for $15 \mathrm{~min}$, at room temperature.

\subsection{Immunostaining for cell surface markers and intracellular cytokines}

The EDTA-treated cell cultures were washed once with FACS buffer prepared as PBS supplemented with $0.5 \%$ of bovine serum albumin-BSA (Sigma, St. Louis, MO, USA) by centrifugation at $600 \times g$ for 7 min at room temperature. Cell pellet was resuspended with $400 \mu \mathrm{l}$ of FACS buffer and $200 \mu \mathrm{l}$ aliquots incubated in $5 \mathrm{ml}$ polystyrene tubes (Becton Dickinson, Frankling Lakes, NJ, USA) in the presence of $60 \mu \mathrm{l}$ of previously diluted anti-canine CD41:320 (rat IgG2a, clone YKIX302.9) or anti-canine CD8-1:40 (rat IgG1, clone YCATE55.9) monoclonal antibodies (mAb), both labeled with fluorescein isothiocyanate dye (FITC) and purchased from SEROTEC (Oxford, UK). Following incubation at room temperature, for $30 \mathrm{~min}$, in the dark, the membrane-stained samples were treated with $3 \mathrm{ml}$ of FACS Lysing/fix Solution (BD Biosciences, San Jose, CA, USA), immediately vortexed and re-incubated for $10 \mathrm{~min}$ at room temperature. After one wash procedure with FACS buffer, the membrane-stained lymphocytes were then permeabilized by incubation for $15 \mathrm{~min}$ with $3 \mathrm{ml}$ of FACS perm-buffer (FACS buffer supplemented with $0.5 \%$ of saponin). After one wash procedure with FACS buffer, cells were incubated in the dark, for $30 \mathrm{~min}$ at room temperature, in the presence of $50 \mu \mathrm{l}$ of PE-labeled antibovine cytokines $\mathrm{mAb}$ that cross-react with canine cytokines (as reported by the manufacturer), including anti-IFN- $\gamma$ (clone CC302) and anti-IL-4 (clone CC303), both purchased from SEROTEC(Oxford, UK). After intracellular staining, the cells were washed once with FACS perm-buffer, followed by one wash step with FACS buffer and finally fixed in FACS FIX Solution. FITC and PE-labeled isotypic controls were included in each batch of experiments.

Flow cytometric measurements were performed on a FACScan instrument (Becton Dickinson, Mountain View, CA) interfaced to an apple G3 FACStation. The Cell-Quest ${ }^{\mathrm{TM}}$ software package provided by the manufacturer (Franklin Lakes, NJ, USA) was used for data acquisition and analysis. A total of 30.000 events were acquired for each preparation.

The analysis of the cytokine profile of $\mathrm{CD}^{+}$and $\mathrm{CD} 8^{+} \mathrm{T}$-cell subsets was performed by first establishing a scattering gate on the lymphocyte population, using laser forward scatter (FSC) versus laser side scatter (SSC) dot plot distributions, followed by quantification of cytokine expressing cells on FL1/FITC versus FL2/PE dot plots combinations. The cytokine ${ }^{+} \mathrm{T}$-cell subsets were identified into the upper-right quadrant on dual color graphs with the FL1/FITC axis representing immunostaining with the anti-cell surface marker FITC-labeled mAb (CD4 or CD8) and FL2/PE corresponding to the immunostaining with the anti-cytokine PE-labeled $\mathrm{mAb}$ (IFN- $\gamma$ or IL-4). The results were expressed as the percentage of double labeled cells (IFN- $\gamma^{+} \mathrm{CD} 4^{+}, \mathrm{IL}-4^{+} \mathrm{CD} 4^{+}$, IFN $-\gamma^{+} \mathrm{CD} 8^{+}$and $\mathrm{IL}-4^{+} \mathrm{CD}^{+}$) within the lymphocyte logical gate.

\subsection{Analysis of nitric oxide (NO) synthesis}

The concentration of nitrite $\left(\mathrm{NO}_{2}{ }^{-}\right)$released in the supernatant of in vitro PBMC cultures was measured using the Griess reaction [28]. Briefly, a $100 \mu$ l aliquot of cell-free culture supernatant was mixed with $100 \mu$ l of Griess reagent (1\% sulphanylamide, $0.1 \%$ naphthylethylene-diamide-dihydrochloride and $2.5 \%$ phos- 
phoric acid, all from Sigma, St. Louis, MO, USA). Following $10 \mathrm{~min}$ of incubation at room temperature, in the dark, the absorbance was measured at $540 \mathrm{~nm}$, using a microplate reader. Each sample was assayed in duplicate and the concentration of nitrite was determined by interpolation from a standard curve constructed using sodium nitrite solutions of known concentration in the range $0-100 \mu \mathrm{M}$. To discount the interference of nitrites already present in the culture medium, data was calculated taking into account the blank for each experiment, assayed by using the medium employed for the in vitro PBMC cultures. The results were first expressed as nitrite concentration $(\mu \mathrm{M})$. The nitrite level was then divided by the number of monocytes added to each in vitro PBMC culture in order to yield the nitric oxide index (nitrite/monocytes).

\subsection{Detection of anti-fixed L. chagasi promastigotes antibodies by flow cytometry-FC-AFPA}

The FC-AFPA procedure was carried out as proposed by de Andrade et al. [29] for the detection of anti-fixed promastigote L. chagasi immunoglobulins. Briefly, in 96-well U-bottom plates (LINBRO, ICN Biomedicals, Inc. Aurora, $\mathrm{OH}$ ), $50 \mu$ l aliquots of the pre-fixed parasite suspension $\left(5.0 \times 10^{5}\right.$ parasites/well) were incubated at $37^{\circ} \mathrm{C}$ for $30 \mathrm{~min}$ in the presence of $50 \mu \mathrm{l}$ of pre-diluted serum samples in PBS-3\% FBS (1:256-1:8,192 for IgG; 1:256-1:4096 for IgG1 and 1:256-1:16,384 for IgG2). Following the incubation, parasites were washed twice with $150 \mu \mathrm{l}$ of PBS-3\% FBS $(1000 \times \mathrm{g}$, $10 \mathrm{~min}, 4^{\circ} \mathrm{C}$ ). The parasites were re-incubated in the dark, for $30 \mathrm{~min}$ at $37^{\circ} \mathrm{C}$ in the presence of $50 \mu$ l of FITC-labeled sheep (putatively anti-IgG and anti-IgG2) and goat (putatively anti-IgG1) polyclonal antibodies anti-canine second step reagents previously diluted in PBS-3\% FBS (anti-IgG 1:1000-cat. A40-105F, anti-IgG1 1:500-cat. A40-120F and anti-IgG2 1:1000-cat. A40-121F), all purchased from Bethyl laboratories Inc. (Montgomery, TX, EUA). After incubation parasites were submitted to two washing procedure using $150 \mu \mathrm{l}$ of PBS-3\% FBS $\left(1000 \times \mathrm{g}, 10 \mathrm{~min}, 4^{\circ} \mathrm{C}\right)$, fixed with $200 \mu \mathrm{l}$ of FACS FIX solution and maintained for at least $30 \mathrm{~min}$, at $4{ }^{\circ} \mathrm{C}$ in the dark, prior the flow cytometric data acquisition. An internal control of the reaction, in which the parasites were incubated in the absence of dog serum, but in the presence of the FITC-labeled secondary reagents, was included in all set of experiments to monitor unspecific bindings. In all batches of FC-AFPA, positive and negative controls were also run to certify the test performance. Flow cytometric acquisition was performed using a FACScalibur ${ }^{\circledR}$ flow cytometer (BD Pharmingen) considering a total of 5000 events per tube. CELLQuest ${ }^{\circledR}$ software package (Franklin Lakes, NJ, USA) was used for data acquisition and analysis. Data analysis was performed by first gating the promastigote forms based on their size and granularity properties on FSC $\times$ SSC dot plots. The relative FITC fluorescence intensity of the selected promastigotes was then quantified on single color fluorescen-1 (FITC/FL1) histograms. The histogram distributions, obtained for the internal control of unspecific binding of the second step reagents, were used to a set up a marker to confine at least $98 \%$ of promastigotes into a region of negative fluorescence intensity. Once established, the marker was used to determine the percentage of positive fluorescent parasites (PPFP) for each tested sample.

\subsection{Statistical analysis}

Statistical analysis was performed using the GraphPad Prism 4.03 software package (San Diego, CA, USA). Data analysis was carried out by ANOVA followed by Tukey's multiple comparison test to evaluate the cytokine and NO profiles between unvaccinated and vaccinated dogs 40 days after the end of the vaccination protocols. Analyses of immunoglobulin reactivity as well as the association between immunoglobulin and cytokine profiles were carried out by Spearman correlation test. In all cases, the differences were considered significant when the probabilities of equality, $p$-values were $<0.05$.

\section{Results}

3.1. Regardless of the distinct cytokine patterns observed in $C D 4^{+}$ and $C D 8^{+} T$-cell subsets, both Leishvaccine and Leishmune ${ }^{\circledR}$ vaccines elicited high levels of T-cell-derived IFN- $\gamma$

Aiming to further focus on the impact of Leishvaccine and Leishmune ${ }^{\circledR}$ vaccines on the T-cell cytokine pattern, herein we have characterized for the first time, the frequency of both IFN- $\gamma^{+}$ and $\mathrm{IL}-4^{+}$T-cells as well as their major subsets (CD4 ${ }^{+}$and $\mathrm{CD}^{+}$) within PBMC collected from unvaccinated and Leishvaccine and Leishmune ${ }^{\circledR}$ vaccinated dogs. For this purpose, PBMC were isolated and submitted to in vitro cultures in the absence (control, CC) or presence of soluble $L$. chagasi antigens (SLA). The frequency of both IFN $-\gamma^{+}$and IL- $4^{+}$T-cell subsets observed in the CC and SLA cultures are presented in Fig. 1. Our data demonstrated that both Leishvaccine and Leishmune ${ }^{\circledR}$ induced increased levels of IFN- $\gamma^{+}$ T-cells as compared with unvaccinated dogs, in both CC and SLA cultures (Fig. 1A). Further analysis highlighted that this phenotype was selectively observed in $\mathrm{CD}^{+} \mathrm{T}$-cells from Leishvaccine and Leishmune ${ }^{\circledR}$ vaccinated dogs, in CC and SLA cultures (Fig. 1B). No changes were observed in the IFN- $\gamma$ synthesis by $\mathrm{CD}^{+} \mathrm{T}$-cells (Fig. 1C). It was interesting to notice that Leishmune ${ }^{\circledR}$ showed no significant levels of IL-4, which corroborate the previous finding about protection in the field studies.

On the other hand, higher levels of IL- $4^{+}$T-cells were observed selectively in the SLA cultures of PBMC from dogs immunized with Leishvaccine as compared to both unvaccinated and Leishmune ${ }^{\circledR}$ vaccinated dogs (Fig. 1D). Further analysis demonstrated that this phenotype were mainly due to IL- $4^{+} \mathrm{CD} 8^{+} \mathrm{T}$-cells (Fig. $1 \mathrm{~F}$ ). Increased percentages of IL- $4^{+} \mathrm{CD} 4^{+} \mathrm{T}$-cells was also observed in Leishvaccine group as compared to unvaccinated dogs, however, selectively in the CC culture (Fig. 1E).

Additional analyses showed significant increase in the IFN$\gamma^{+} /$IL- $4^{+}$T-cells ratio in CC cultures of PBMC from both Leishvaccine and Leishmune ${ }^{\circledR}$ vaccinated dogs as compared to unvaccinated dogs. However, increased IFN- $\gamma^{+} / \mathrm{IL}^{-} 4^{+} \mathrm{T}$-cells ratio was selectively observed in Leishmune ${ }^{\circledR}$ vaccinated dogs when analyzing the SLA cultures. Interestingly, the IFN- $\gamma^{+} / \mathrm{IL}-4^{+} \mathrm{T}$-cells ratio observed in the SLA cultures for Leishmune ${ }^{\circledR}$ vaccinated dogs was higher than that observed in the CC culture of PBMC obtained from these animals (Fig. 1G).

The cytokine patterns of T-cell subsets from Leishvaccine and Leishmune ${ }^{\circledR}$ vaccinated dogs are illustrated by flow cytometry dot plots representatives of CC (Fig. 1H) and SLA cultures (Fig. 1I). The analysis of cytokine ${ }^{+}$T-cell subsets in the PMA-induced cultures confirmed the cell viability of all samples, as demonstrated by high levels of IFN $-\gamma^{+}$and IL- $4^{+}$cells within both, $\mathrm{CD} 4^{+}$and $\mathrm{CD} 8^{+}$T-cell subsets (Fig. 1J).

\subsection{Despite triggering distinct cytokine profiles, both} Leishvaccine and Leishmune ${ }^{\circledR}$ were able to shift the overall cytokine balance toward a type-1 immune response

Taking the general hypothesis that a fine balance between IFN$\gamma$ and IL-4 profile is more relevant that a shift toward a polarized cytokine pattern, we have further characterize for each animal within the Leishvaccine and Leishmune ${ }^{\circledR}$ vaccinated dogs, the overall balance of IFN- $\gamma$ and IL- 4 derived from $\mathrm{CD} 4^{+}$and $\mathrm{CD}^{+}{ }^{+}$T-cell subsets. This strategy allows the characterization of the resultant cytokine profile from T-cells driven by the vaccination interven- 

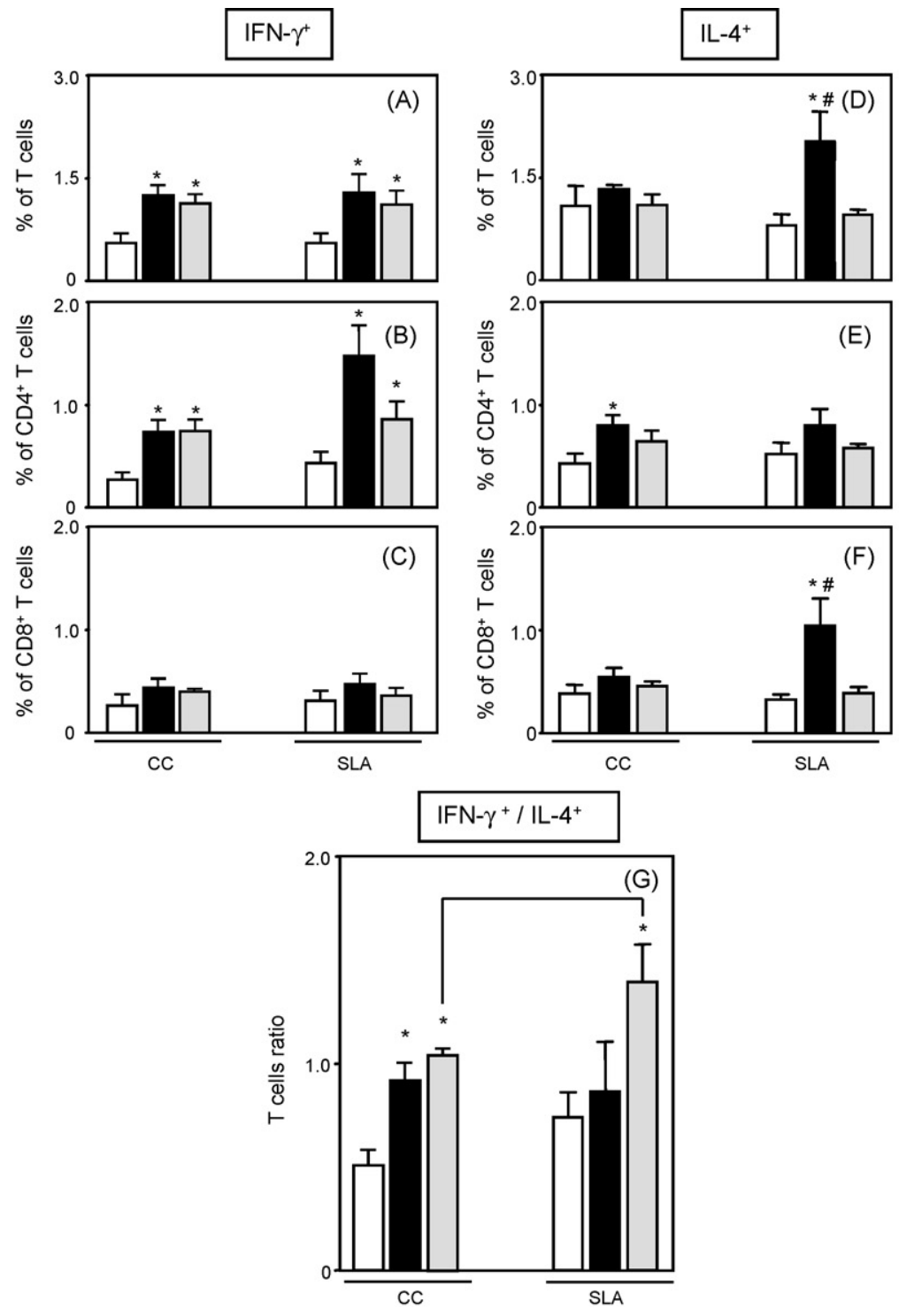

(H)
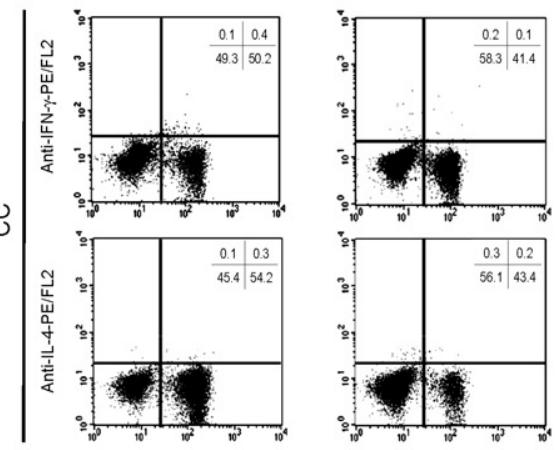

(I)
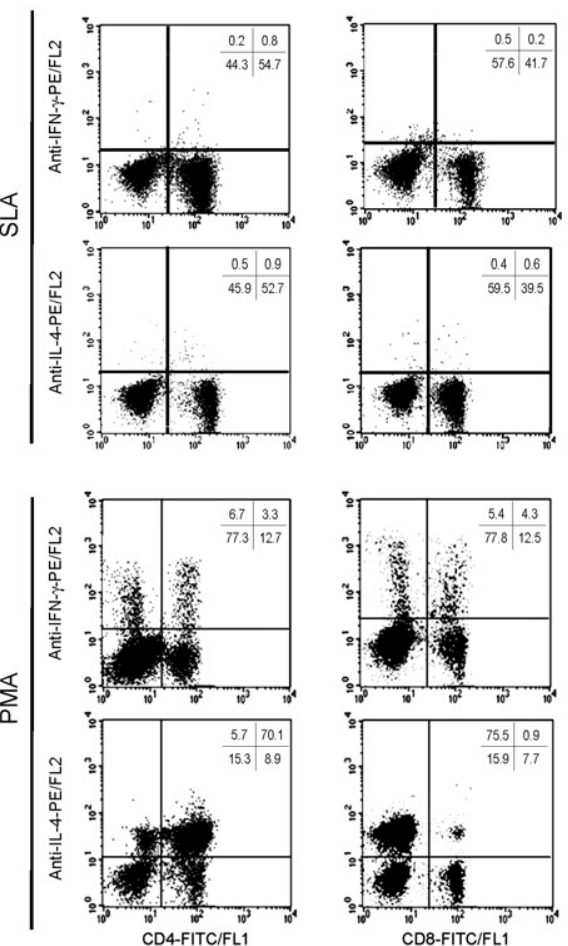

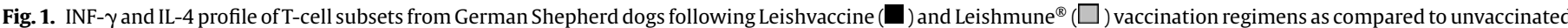

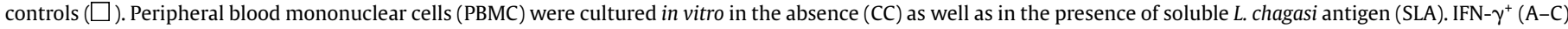

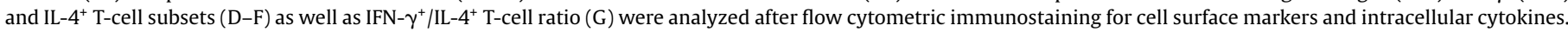

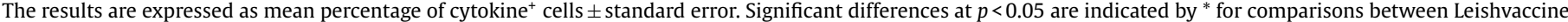

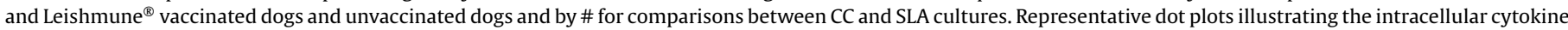
profile of T-cell subsets in the CC, SLA and PMA-stimulated positive control cultures are provided (H-J, respectively).

tion. To establish the overall cytokine balance data obtained by flow cytometry the results were further transformed as proposed by Vitelli-Avelar et al. [30]. This new strategy consisted of a four step platform that includes: 1st, the establishment of "low" and "high" cytokine-producers based on global median of cytokine ${ }^{+} \mathrm{T}-$ cell subsets calculated from the whole range of values obtained for the whole study population (all dogs) including unvaccinated dogs, Leishvaccine and Leishmune ${ }^{\circledR}$ vaccinated dogs (Fig. 2); 2nd, the construction of color diagrams for each group of animals (Unvaccinated, Leishvaccine and Leishmune ${ }^{\circledR}$ vaccinated dogs) showing the "cytokine pattern" of "low" and "high" cytokine-producers within $\mathrm{CD}^{+}$and $\mathrm{CD}^{+} \mathrm{T}$-cell subsets (Fig. 3A); 3rd, the compilation of the "cytokine balance" defined as predominant low cytokineproducers, inflammatory, regulatory or mixed cytokine-producers within T-cells (Fig. 3B) and 4th, the assemble of the "overall cytokine balance" as the proportion of high inflammatory, regulatory or mixed cytokine producers within T-cells (Fig. 3C).
The analysis of the "cytokine pattern" of T-cell subsets, based on the three major classes of cytokine-producers named as "low" cytokine-producers, "high" IFN- $\gamma$-producers and "high" IL-4-producers, observed in color diagram, demonstrated that among unvaccinated dogs there is a predominance of "low" cytokine-producers within all T-cell subsets as compared to Leishvaccine and Leishmune ${ }^{\circledR}$ vaccinated dogs, with four animals (Dog\#2, 3, 5 and 8) showing a general profile of low cytokineproducers (Figs. 2 and 3A). On the other hand, the Leishvaccine and Leishmune ${ }^{\circledR}$ vaccinated dogs showed predominance of high cytokine-producers, with only one animal from the Leishmune group (Dog\#7) displaying a general profile of low cytokineproducer (Fig. 2A).

Taking the "cytokine balance" within $\mathrm{CD}^{+}$and $\mathrm{CD}^{+}$T-cell subsets, our data re-emphasized the predominant pattern of lowcytokine producers within the unvaccinated dogs and pointed out the existence of a distinct cytokine balance between Leishvac- 

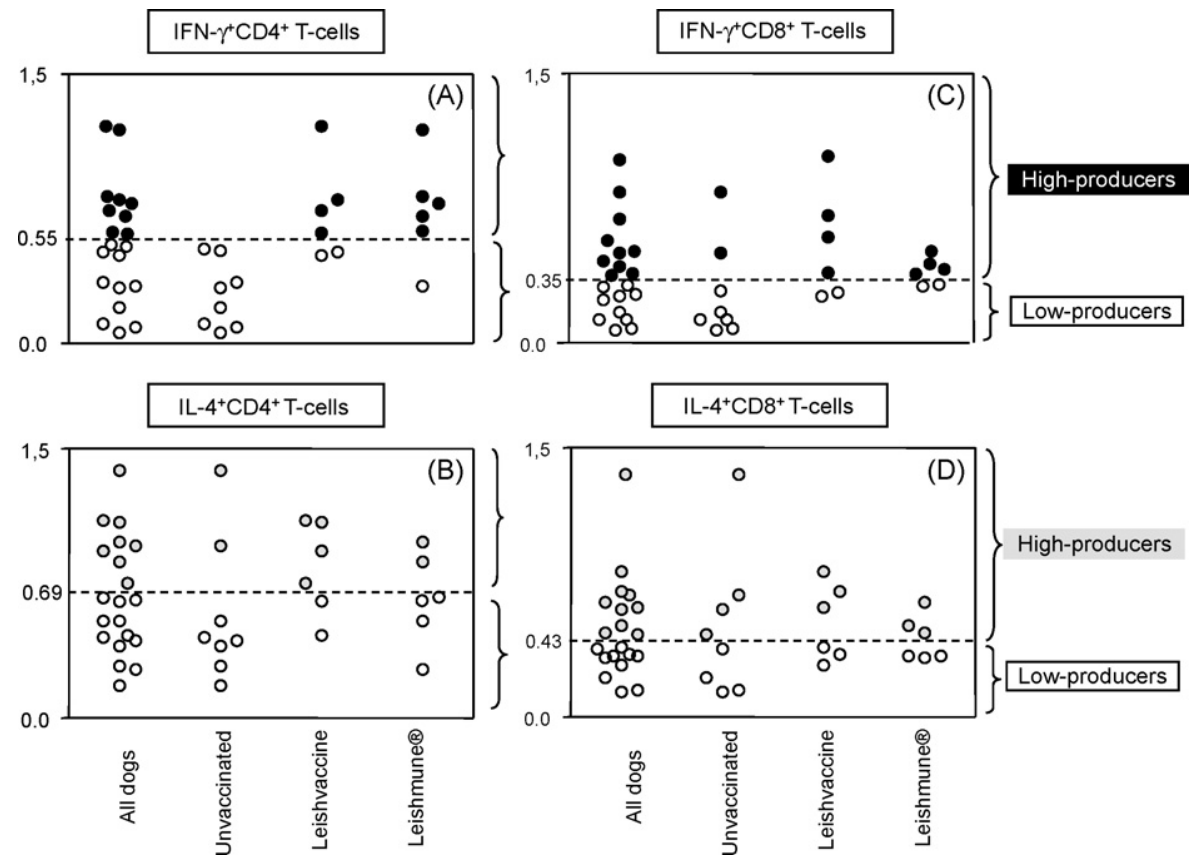

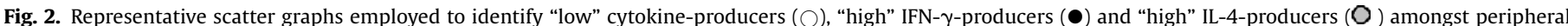

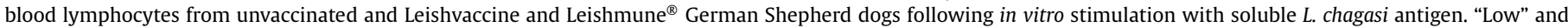

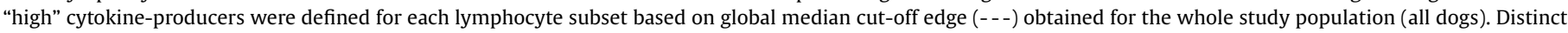
cut-offs were employed for IFN- $\gamma^{+} \mathrm{CD} 4^{+}(\mathrm{A}), \mathrm{IL}-4^{+} \mathrm{CD} 4^{+}$T-cells (B), IFN- $\gamma^{+} \mathrm{CD} 8^{+}$(C) and IL- $4^{+} \mathrm{CD} 8^{+} \mathrm{T}$-cells (D).

cine and Leishmune ${ }^{\circledR}$ vaccinated dogs with distinct predominance of animals displaying inflammatory or mixed cytokine profiling (Fig. 3B).

The analysis of the "overall cytokine balance" demonstrated that $50 \%$ of the unvaccinated group is confined within low cytokine-producers (Fig. 3C, bar chart) and that amongst the high cytokine-producers, most animals (75\%) presented a predominance of IL-4 cytokine profile (Fig. 3C, pie chart). On the other hand, Leishvaccine induced the pattern of high cytokine-producers in all vaccinated dogs (Fig. 3C, bar chart). In fact, the Leishvaccine drove a predominant IFN- $\gamma$ profile $(50 \%)$ or a mixed IFN- $\gamma \approx$ IL- 4 pattern (16.7\%) in $66.7 \%$ of the vaccinated dogs, suggesting a protective pattern (Fig. 3C, pie chart). The Leishmune ${ }^{\circledR}$ was capable to shift the overall cytokine profile toward high cytokine-producers in most (87.5\%) vaccinated dogs (Fig. 3, bar chart). Interestingly, the analysis of Leishmune ${ }^{\circledR}$ vaccinated dogs within the high cytokine-producers demonstrated a shift toward a predominant IFN- $\gamma$ profile $(83.3 \%)$ or a mixed IFN- $\gamma \approx$ IL-4 pattern (16.7\%) representing a protective pattern (Fig. 3C, pie chart).

\subsection{Leishmune ${ }^{\circledR}$ vaccination induced high nitric oxide index (nitrite/monocytes) following in vitro PBMC cultures even in the presence of soluble L. chagasi antigens}

The induction of nitric oxide (NO) is one of the major effector mechanisms leading the Leishmania elimination by activated phagocytes $[23,31,32]$. Previous report has pointed out that canine macrophages from killed Leishmania infantum vaccinated dogs are able to perform Leishmania killing throughout NO-dependent mechanisms [23]. In attempt to characterize the ability of Leishvaccine and Leishmune ${ }^{\circledR}$ to induce the NO production by peripheral blood monocytes, we have investigated the levels of nitrite in the supernatants of in vitro PBMC cultures following Leishvaccine and Leishmune ${ }^{\circledR}$ vaccination. Despite no differences in the levels of nitrite observed in both CC and SLA cultures (data not shown), the analyses of nitric oxide index (nitrite/monocytes), taking in account the number of monocytes added into each in vitro PBMC culture, pointed out that Leishmune ${ }^{\circledR}$ vaccines displayed in the CC cultures, higher mean nitric oxide index as compared to unvaccinated and Leishvaccine immunized dogs. Interestingly, monocytes from Leishmune ${ }^{\circledR}$ vaccines also presented higher ability to produce NO as compared to unvaccinated dogs, even in the presence of soluble L. chagasi antigens (Fig. 4).

3.4. Distinct pattern of anti-L. chagasi IgG subclasses were observed in Leishvaccine and Leishmune ${ }^{\circledR}$ vaccinated dogs

Aiming to further characterize the immune response triggered by Leishvaccine and Leishmune ${ }^{\circledR}$ immunization, we have accessed the profile of seric anti-L. chagasi IgG in a broader range of vaccinated dogs, including 24 dogs, categorized into two subgroups referred as Leishvaccine and Leishmune ${ }^{\circledR}$. Data analysis demonstrated that all vaccinated dogs seroconvert after immunization as confirmed by seropositivity in indirect immunofluorescence assay test (IFAT). Data analysis did not demonstrate any significant differences in the mean IFAT titers between Leishvaccine and Leishmune ${ }^{\circledR}$ vaccinated dogs (Fig. 5A). Additional analysis of anti-L. chagasi IgG was performed by semi-quantitative flow cytometric detection of anti-fixed $L$. chagasi promastigotes FCAFPA-IgG, IgG1 and IgG2 [29]. Our data demonstrated that despite no changes in the FC-AFPA-IgG profiling (Fig. 5B), the median FC-AFPA-IgG1 and IgG2 PPFP values suggested distinct pattern of sero-reactivity between Leishvaccine and Leishmune ${ }^{\circledR}$ vaccinated dogs (Fig. 5C and D). In fact, higher median FC-AFPA-IgG1 reactivity was observed in Leishvaccine group (Fig. 5C), whereas higher median FC-AFPA-IgG2 reactivity was detected in Leishmune ${ }^{\circledR}$ vaccinated dogs (Fig. 5D). Further analyses demonstrated a positive correlation between FC-AFPA-IgG with both FC-AFPA-IgG1 and FCAFPA-IgG2 in Leishvaccine immunized dogs (Fig. 5E and F), while in Leishmune ${ }^{\circledR}$ vaccinated dogs a positive correlation was observed selectively between FC-AFPA-IgG and FC-AFPA-IgG2 (Fig. 5G and $\mathrm{H})$.

The dynamic interplay of IL-4 in regulating the production of IgC subclasses has been recently documented in humans [33], suggest- 
(A)

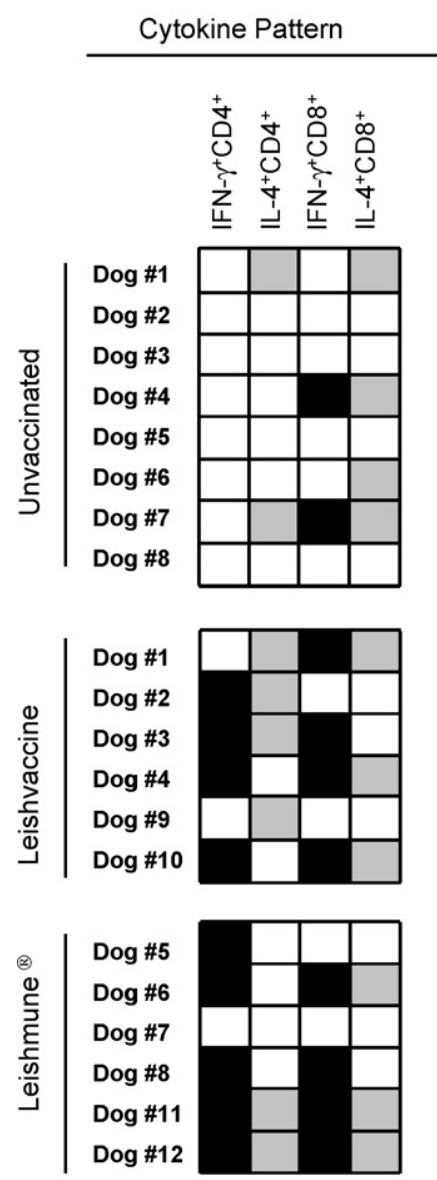

(B)

Cytokine Balance
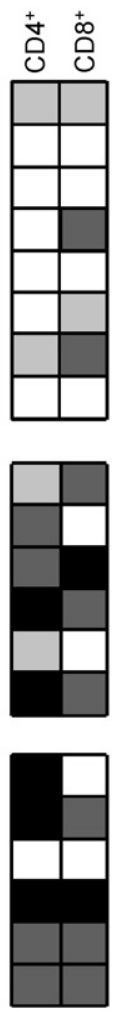

(C)

Overall Cytokine Balance

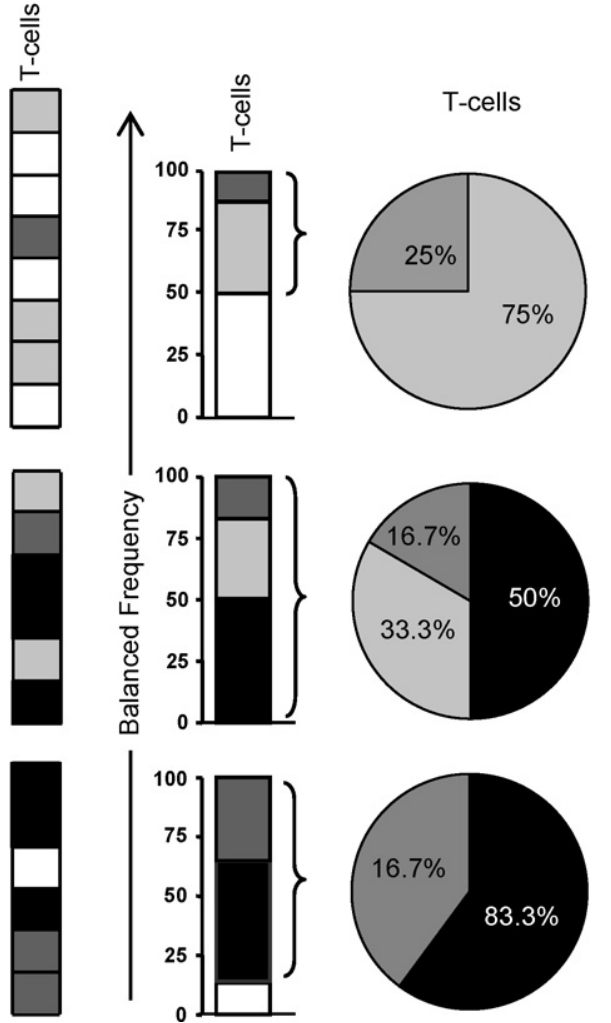

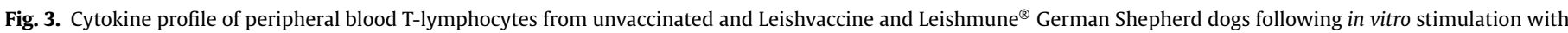

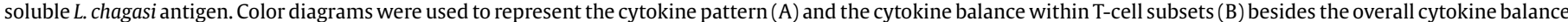

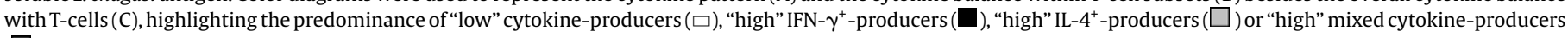

( $\square$ ). Pie charts represent the percentage of animals displaying a given T-cells overall cytokine balance selectively amongst the "high" cytokine-producers.

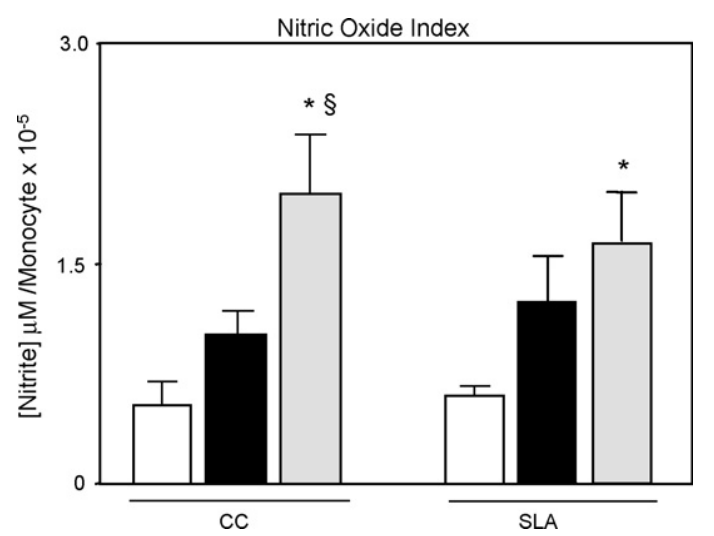

Fig. 4. Production of nitric oxide (NO) by peripheral blood monocytes from German Shepherd dogs following Leishvaccine $(\square)$ and Leishmune ${ }^{\circledR}(\square)$ vaccination regimens as compared to unvaccinated controls $(\square)$. As an indirect measurement of NO production, the Griess reaction was used to determine the nitrite levels in the supernatants of in vitro PBMC cultures performed in the absence (CC) as well as in the presence of soluble $L$. chagasi antigen (SLA). The results are expressed as nitric oxide index that represent the nitrite level $(\mu \mathrm{M})$ divided by the number of monocytes added to each in vitro PBMC culture in order to yield the nitric oxide index (nitrite/monocytes). Significant differences at $p<0.05$ are indicated by ${ }^{*}$ or $\S$ for comparisons between Leishmune ${ }^{\circledR}$ and unvaccinated or Leishvaccine immunized dogs, respectively. ing a temporal role for this cytokine in humoral immune responses to specific pathogens. Aiming to investigate whether the IL-4 versus IgG interplay take place during Leishvaccine and Leishmune vaccination, we have performed a correlation analysis between the IgG reactivity, detected at sera dilution 1:256 and the frequency of IL- $4^{+} \mathrm{T}$-cells, focusing specifically on $\mathrm{CD}^{+} \mathrm{T}$-cells, since they were pointed out as an important source of IL-4 in Leishvaccine immunized dogs, specially following in vitro SLA stimulation of PBMC cultures (Fig. 1F). Our findings demonstrated that a positive correlation could be observed between the frequency of SLA-induced IL $-4^{+} \mathrm{CD} 8^{+} \mathrm{T}$-cells and the reactivity of anti-L. chagasi IgG, selectively in the dogs immunized with Leishvaccine (Fig. 5I). No significant correlations were found between the anti-Leishmania IgG profiling (including IgG, IgG1 and IgG2) and the frequency of IL- $4^{+} \mathrm{CD} 4^{+} \mathrm{T}-$ cells (Fig. 5J) neither the frequency of SLA-induced IFN- $\gamma^{+}$T-cell subsets (data not shown).

\section{Discussion}

Despite the large amount of immunological data derived from clinical studies of CVL [34-36] there are still limited data available regarding the immune response triggered by anti-CVL vaccines [8-14,24,37-40]. The present work attempted to perform a phenotypic/functional analysis of canine peripheral blood cells to understand the immunological mechanisms related to immunogenicity elicited by Leishvaccine and Leishmune ${ }^{\circledR}$, focusing on three 

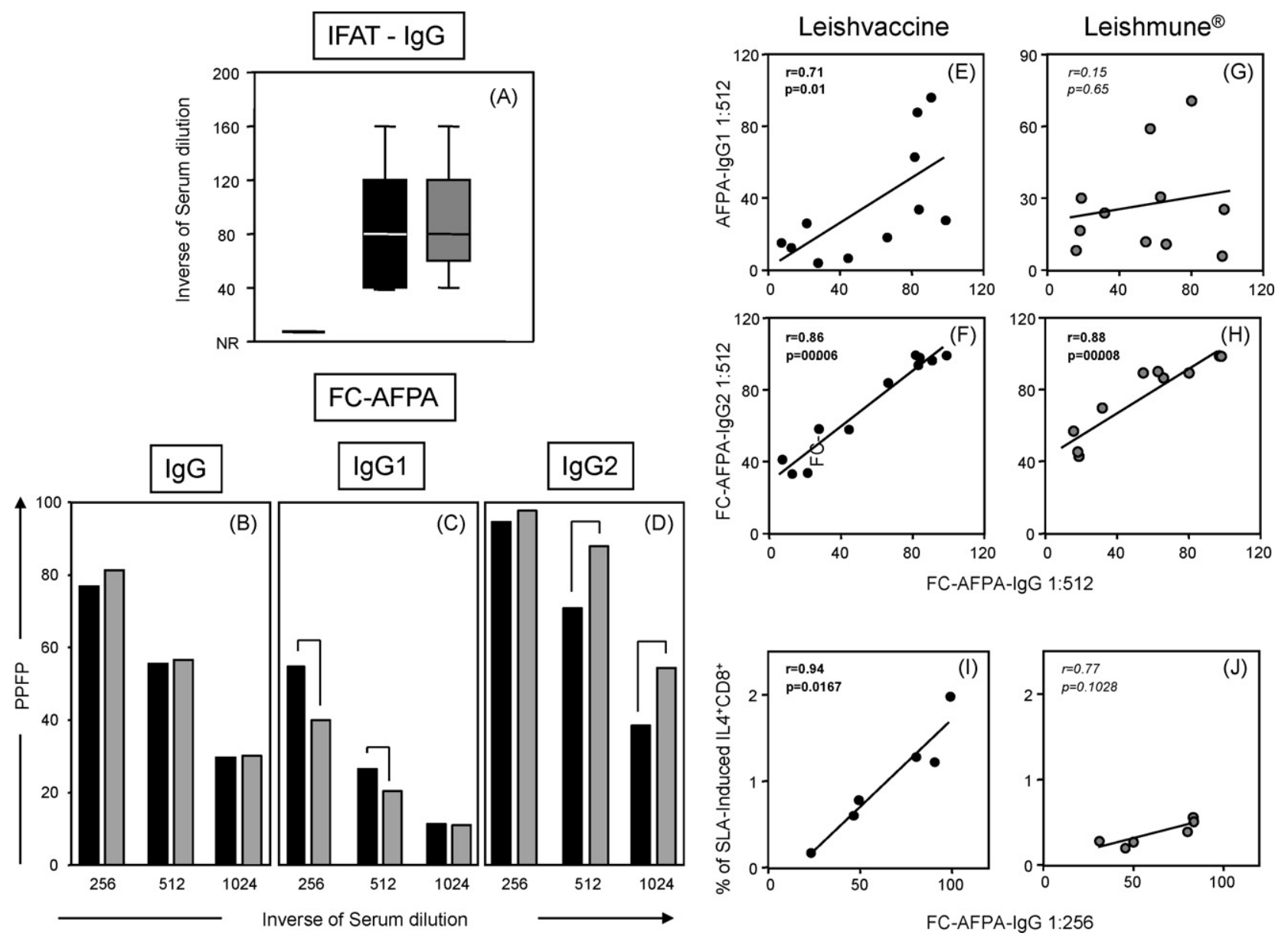

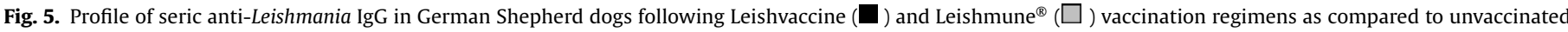

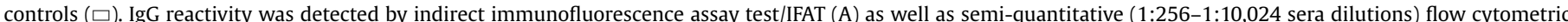

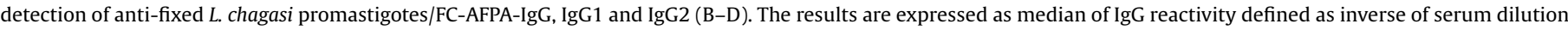

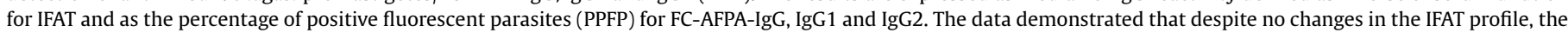

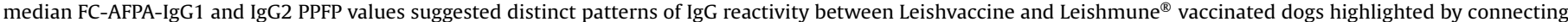

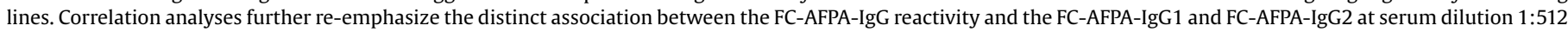

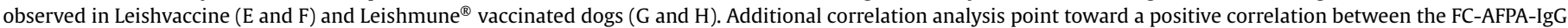
reactivity at serum dilution 1:256 and the \% of SLA-induced IL- $4^{+} \mathrm{CD} 8^{+} \mathrm{T}$-cells.

major aspects of the immune response, including: T-cell-derived cytokines, nitric oxide production by peripheral blood monocytes and seric anti-L. (Leishmania) chagasi IgG subclass patterns.

Cumulative studies show that the protective mechanisms are mainly associated with a specific type- 1 immune response, specially linked with high IFN- $\gamma$ secretion, whereas the role of type- 2 immune response in the susceptibility to Leishmania infection dogs still remains to be elucidated $[15,33,36,41-44]$. In this context, a critical matter for screening and development of anti-leishmanial vaccines in CVL is to define Leishmania antigens and adjuvant systems that elicit a favorable and sustained type-1 cytokine environment in vivo. Herein, our data showed that despite the intrinsic differences in the immune response, intervention with either Leishvaccine or Leishmune ${ }^{\circledR}$ vaccines was accompanied by high levels of IFN- $\gamma^{+}$T-cells, mainly due to an increase of the percentage of IFN- $\gamma^{+} \mathrm{CD}^{+}$T-cell subset, with an expressive increase observed upon SLA-stimuli, suggesting that both vaccines have the promising ability to elicit the establishment of anti-Leishmania immune mechanisms. Additionally, Leishvaccine immunized dogs showed increased levels of IL- $4^{+}$T-cells, with involvement of both $\mathrm{CD} 4^{+}$ and $\mathrm{CD}^{+}$T-cell subsets. Consistent with this distinct cytokine profiling, we have previously reported that while Leishvaccine is able to trigger a mixed immunological profile involving changes in $\mathrm{CD}^{+}$and $\mathrm{CD}^{+}$T-cells as well as in the B-cell compartment,
Leishmune ${ }^{\circledR}$ elicited selective changed on the cellular adaptive immune response, mainly linked to the activation $\mathrm{CD}^{+} \mathrm{T}$-cell [24]. Since $\mathrm{CD} 4^{+} \mathrm{T}$-cells are the major source of IFN- $\gamma$ and the activation of CD8+ T-cells is an important phenotypic features observed in the peripheral blood of Leishvaccine and Leishmune ${ }^{\circledR}$ vaccines, we hypothesize that the cross-talk between $\mathrm{CD} 4^{+}$and $\mathrm{CD} 8^{+} \mathrm{T}$-cells may underlay the protective mechanism triggered by these immunobiologicals. In this context, the $\mathrm{CD} 4^{+} \mathrm{T}$-cells derived INF- $\gamma$ could represents the link to activate the $\mathrm{CD} 8^{+} \mathrm{T}$-cell functions, already reported to play a crucial role in controlling the primary Leishmania infection in concurrence with the early shift in the type- 2 toward a type- 1 immune response $[45,46]$. It is possible that the multiple interactions induced by the whole crude $L$. amazonensis antigens (carbohydrate, protein, lipid and nucleic acid) would be the basis for the mixed IFN- $\gamma$ and IL- 4 cytokine pattern following immunization with Leishvaccine, characterizing the multiplicity of interactions with a wide range of cell surface receptors distributed on several cell subsets. On the other hand, the purified nature of FML antigen (glycoprotein) support the more selective IFN- $\gamma$ linked cytokine profile observed in Leishmune ${ }^{\circledR}$ vaccines, with selective involvement of T-cells. We have previously suggested that besides the molecular nature of the antigens the adjuvants could also affect the properties of cell-mediated immunity [24]. We hypothesized that the BCG-based adjuvant in association with the complex whole crude $L$. 
amazonensis antigen formulation used in Leishvaccine could potentiate the establishment of the mixed cytokine profile observed following vaccination. On the other hand, the saponin-based adjuvant used in Leishmune ${ }^{\circledR}$ would prompt a more selective cellular immune response as previously reported [37].

There is a current consensus amongst immunologists that rather than a shift toward a polarized cytokine pattern, the fine balance between type- 1 and type- 2 cytokines derived from distinct cell sources, may be more relevant for directing immune-mediated mechanisms that drive the disease outcome, as wells as critical for determining the success of immunoprophylactic tools. We have recently proposed a novel strategy to assess the overall cytokine profile of circulating leukocytes, since the conventional strategies may not capture the global cytokine imprint, and does not reflect the panoramic cytokine profile of the wide range of circulating T-cell subsets [30]. Using this approach, we have characterized the T-cell overall cytokine profile triggered by Leishvaccine and Leishmune ${ }^{\circledR}$ vaccination regimens. Our results highlight that while a resultant type-1 cytokine pattern was observed in $50 \%$ of dogs immunized with Leishvaccine, a predominance of type-1 cytokine profile was observed in over $80 \%$ of Leishmune ${ }^{\circledR}$ vaccines. A predominant type- 2 cytokine pattern was the hallmark of unvaccinated dogs. This type- 2 related cytokine profile has been already reported in unvaccinated dogs [47]. Together, our cytokine findings highlighted that both immunobiologicals display potential applicability to drive a type-2 cytokine pattern observed in unvaccinated dogs toward a type-1, presumably protective against CVL.

It has been suggested that the IFN- $\gamma$-induced L-arginine nitric oxide (NO) pathway mediated by monocytes/macrophages is one of the major effector mechanism involved in the protective immune response in dogs infected with Leishmania $[19,20]$. Our data showed that Leishmune ${ }^{\circledR}$ vaccinated dogs presented increased levels of NO producing monocytes. Besides with the higher levels of IFN$\gamma^{+} \mathrm{CD} 4^{+}$T-cells, the Leishmune ${ }^{\circledR}$ immunized dogs may possess the immunological events needed to establish a anti-Leishmania protective immune response. Pinelli et al. [20] have reported that recombinant canine IFN- $\gamma$ alone is sufficient to induce in vitro NO production by canine macrophages. These findings re-emphasize that Leishmune ${ }^{\circledR}$ has the ability to activate phagocytes and support its high-quality immunogenic potential against CVL. Despite NO production and anti-leishmanial activity have been already reported in macrophages from dogs immunized with whole killed L. infantum promastigotes antigen [23], our data did not show alterations in the in vitro NO synthesis by monocytes from Leishvaccine immunized dogs, even in the presence of SLA. It is possible that the high levels of IL- $4^{+}$T-cells observed in these animals may count for the impaired NO production by circulating monocytes.

The humoral immune response has been usually associated with worsening outcome of CVL [48]. However, it has been proposed that differential responses of IgG subclasses can be in fact, indicative of dichotomous antibody response following anti-CVL immunoprophylaxis with Leishvaccine and Leishmune ${ }^{\circledR}[38,49]$. Our results re-emphasize the existence of this dichotomous anti-Leishmania immunoglobulin profile, demonstrating that the Leishvaccine tend to induce higher levels of anti-Leishmania IgG1, whereas higher levels anti-Leishmania IgG2 are more likely to be observed in the Leishmune ${ }^{\circledR}$ vaccinated dogs. These findings are in agreement and re-enforce those previously reported by Fujiwara et al. [38] and de Oliveira Mendes et al. [49]. Additional analysis demonstrated the existence of a positive correlation between the reactivity of antiLeishmania IgG with both IgG1 and IgG2 in Leishvaccine immunized dogs. On the other hand, Leishmune ${ }^{\circledR}$ vaccinated dogs, a positive correlation was observed selectively between anti-Leishmania IgG and IgG2. Moreover, our findings demonstrated a positive correlation between the frequency of SLA-induced IL-4+CD8 ${ }^{+}$T-cells and the reactivity of anti-L. chagasi IgG, selectively in the dogs immu- nized with Leishvaccine, re-enforcing that the IL-4 triggered by this vaccine may also interplay a role interfering on the anti-IgG subclasses profile.

Altogether, our data pointed out to distinct immunological profiles elicited by Leishvaccine and Leishmune ${ }^{\circledR}$, with the first triggering a mixed (IFN- $\gamma$ and IL-4) cytokine pattern besides upper levels of anti-Leishmania IgG1, whereas the former induced an immunological pattern characterized by enhanced levels of IFN$\gamma$, NO and anti-Leishmania IgG2. It is important to notice that the ability of both immunobiologicals to activate T-cell-derived IFN$\gamma$ synthesis suggested their high-quality immunogenic potential against CVL. These findings added support to further investigation focusing on perspectives of rational improvement of the antigenic composition as well as the adjuvant nature used for these vaccines formulation that might impact their immunoprophylactic effectiveness in the management of CVL.

\section{Acknowledgements}

The authors would like to thanks the members of the Laboratório de Biomarcadores de Diagnóstico e Monitoração at Centro de Pesquisas René Rachou, FIOCRUZ-MG for providing invaluable technical assistance during this study. We are thankful to the Polícia Militar de Minas Gerais for their support with the dog management. This work was supported by CPqRR/FIOCRUZMG, PAPES V/CNPq/FIOCRUZ and FAPEMIG/BR/grant: EDT-236903. O.A.M.F., W.M., A.B.R., M.N.M. are grateful to Conselho Nacional de Desenvolvimento Científico e Tecnológico-CNPq-Brasil for PQfellowships.

\section{References}

[1] Desjeux P. Leishmaniasis: current situation and new perspectives. Comp Immunol Microbiol Infect Dis 2004;27:305-18.

[2] Gramiccia M, Gradoni L. The current status of zoonotic leishmaniases and approaches to disease control. Int J Parasitol 2005;35:1169-80.

[3] Lainson R, Rangel EF. Lutzomyia longipalpis and the eco-epidemiology of American visceral leishmaniasis, with particular reference to Brazil: a review. Mem Inst Oswaldo Cruz 2005;100:811-27.

[4] Tesh RB. Control of zoonotic visceral leishmaniasis: is it time to change strategies? Am J Trop Med Hyg 1995;52:287-92.

[5] World Health Organization. Leishmaniasis, fourteenth programme report. UNDP/World Bank/Special Programme for Research and Training in Tropical Diseases (TDR). Tropical disease research progress 1997-1998. Geneva: World health Organization; 1999. p. 1-6.

[6] Dantas-Torres F. Leishmune vaccine: the newest tool for prevention and control of canine visceral leishmaniosis and its potential as a transmission-blocking vaccine. Vet Parasitol 2006;141:1-8.

[7] Vanloubbeeck Y, Jones DE. The immunology of Leishmania infection and the implications for vaccine development. Ann NY Acad Sci 2004;1026:267-72.

[8] Borja-Cabrera GP, Santos FN, Bauer FS, Parra LE, Menz I, Morgado AA, et al. Immunogenicity assay of the Leishmune vaccine against canine visceral leishmaniasis in Brazil. Vaccine 2008;26:4991-7.

[9] Nogueira FS, Moreira MA, Borja-Cabrera GP, Santos FN, Menz I, Parra LE, et al. Leishmune vaccine blocks the transmission of canine visceral leishmaniasis: absence of Leishmania parasites in blood, skin and lymph nodes of vaccinated exposed dogs. Vaccine 2005;23:4805-10.

[10] Palatnik-de-Sousa CB, Barbosa Ade F, Oliveira SM, Nico D, Bernardo RR, Santos WR, et al. FML vaccine against canine visceral leishmaniasis: from secondgeneration to synthetic vaccine. Expert Rev Vaccines 2008;7:833-51.

[11] Parra LE, Borja-Cabrera GP, Santos FN, Souza LO, Palatnik-de-Sousa CB, Menz I Safety trial using the Leishmune vaccine against canine visceral leishmaniasis in Brazil. Vaccine 2007;25:2180-6.

[12] da Silva VO, Borja-Cabrera GP, Correia Pontes NN, de Souza EP, Luz KG, Palatnik M, et al. A Phase III trial of efficacy of the FML vaccine against canine kala-azar in an endemic area of Brazil (São Gonçalo do Amarante RN). Vaccine 2001;19:1082-92.

[13] Borja-Cabrera GP, Correia Pontes NN, da Silva VO, Paraguai de Souza E, Santos WR, Gomes EM, et al. Long lasting protection against canine kala-azar using the FML-QuilA saponin vaccine in an endemic area of Brazil (São Gonçalo do Amarante). Vaccine 2002;20:3277-84

[14] Saraiva EM, de Figueiredo Barbosa A, Santos FN, Borja-Cabrera GP, Nico D, Souza LO, et al. The FML-vaccine (Leishmune) against canine visceral leishmaniasis: a transmission blocking vaccine. Vaccine 2006;24:2423-31.

[15] Barbiéri CL. Immunology of canine leishmaniasis. Parasite Immunol 2006;28:329-37. 
[16] Heinzel FP, Sadick MD, Mutha SS, Locksley RM. Production of interferon gamma, interleukin 2 , interleukin 4 , and interleukin 10 by CD4+ lymphocytes in vivo during healing and progressive murine leishmaniasis. Proc Natl Acad Sci USA 1991;88:7011-5.

[17] Holaday BJ, Sadick MD, Wang ZE, Reiner SL, Heinzel FP, Parslow TG, et al. Reconstitution of Leishmania immunity in severe combined immunodeficient mice using Th1- and Th2-like cell lines. J Immunol 1991;147:1653-8.

[18] Scharton TM, Scott P. Natural killer cells are a source of interferon gamma that drives differentiation of CD4+ T cell subsets and induces early resistance to Leishmania major in mice. J Exp Med 1993;178:567-77.

[19] Vouldoukis I, Drapier JC, Nüssler AK, Tselentis Y, Da Silva OA, Gentilini M, et al. Canine visceral leishmaniasis: successful chemotherapy induces macrophage antileishmanial activity via the L-arginine nitric oxide pathway. Antimicrob Agents Chemother 1996;40:253-6.

[20] Pinelli E, Gebhard D, Mommaas AM, van Hoeij M, Langermans JA, Ruitenberg EJ, et al. Infection of a canine macrophage cell line with Leishmania infantum: determination of nitric oxide production and anti-leishmanial activity. Vet Parasitol 2000;92:181-9.

[21] Santos-Gomes GM, Rosa R, Leandro C, Cortes S, Romão P, Silveira H. Cytokine expression during the outcome of canine experimental infection by Leishmania infantum. Vet Immunol Immunopathol 2002;88:21-30.

[22] Strauss-Ayali D, Baneth G, Shor S, Okano F, Jaffe CL. Interleukin-12 augments a Th1-type immune response manifested as lymphocyte proliferation and interferon gamma production in Leishmania infantum-infected dogs. Int J Parasitol 2005;35:63-73.

[23] Panaro MA, Acquafredda A, Lisi S, Lofrumento DD, Mitolo V, Sisto M, et al. Nitric oxide production by macrophages of dogs vaccinated with killed Leishmania infantum promastigotes. Comp Immunol Microbiol Infect Dis 2001:24:187-95.

[24] Araújo MS, de Andrade RA, Vianna LR, Mayrink W, Reis AB, Sathler-Avelar R, et al. Despite Leishvaccine and Leishmune trigger distinct immune profiles, their ability to activate phagocytes and CD8+ T-cells support their highquality immunogenic potential against canine visceral leishmaniasis. Vaccine 2008;26:2211-24.

[25] Mayrink W, Genaro O, Dias M, da Costa CA, Michalick MS, Melo MN, et al. Vaccination of dogs against Leishmania (Viannia) braziliensis. Rev Inst Med Trop S Paulo 1990;32:67-9.

[26] Camargo EP. Growth and differentiation in Trypanosoma cruzi. I. Origin of metacyclic trypanosomes in liquid media. Rev Inst Med Trop São Paulo 1964;6:93-100.

[27] Lowry OH, Rosebrough NJ, Farr AL, Randall RJ. Protein measurement with the Folin phenol reagent. J Biol Chem 1951;193:265-75.

[28] Green LC, Wagner DA, Glogowski J, Skipper PL, Wishnok JS, Tannenbaum SR. Analysis of nitrate, nitrite, and [15N]nitrate in biological fluids. Anal Biochem 1982;126:131-8.

[29] de Andrade RA, Reis AB, Gontijo CM, Braga LB, Rocha RD, Araújo MS, et al. Clinical value of anti-Leishmania (Leishmania) chagasi IgG titers detected by flow cytometry to distinguish infected from vaccinated dogs. Vet Immunol Immunopathol 2007; 116:85-97.

[30] Vitelli-Avelar DM, Sathler-Avelar R, Teixeira-Carvalho A, Pinto Dias JC, Gontijo ED, Faria AM, et al. Strategy to assess the overall cytokine profile of circulating leukocytes and its association with distinct clinical forms of human Chagas disease. Scand J Immunol 2008 Sep:18 [Epub ahead of print].

[31] Mauël J, Ransijn A, Buchmüller-Rouiller Y. Killing of Leishmania parasites in activated murine macrophages is based on an L-arginine-dependent process that produces nitrogen derivatives. J Leukoc Biol 1991;49:73-82.

[32] Liew FY, Xu D, Chan WL. Immune effector mechanism in parasitic infections. Immunol Lett 1999;65:101-4.

[33] Avery DT, Bryant VL, Ma CS, de Waal Malefyt R, Tangye SG. IL-21-induced isotype switching to IgG and IgA by human naive B cells is differentially regulated by IL-4. J Immunol 2008;181:1767-79.
[34] Giunchetti RC, Martins-Filho OA, Carneiro CM, Mayrink W, Marques MJ, Tafuri $\mathrm{WL}$, et al. Histopathology, parasite density and cell phenotypes of the popliteal lymph node in canine visceral leishmaniasis. Vet Immunol Immunopatho 2008;121:23-33.

[35] Reis AB, Teixeira-Carvalho A, Giunchetti RC, Guerra LL, Carvalho MG, Mayrink W, et al. Phenotypic features of circulating leucocytes as immunological markers for clinical status and bone marrow parasite density in dogs naturally infected by Leishmania chagasi. Clin Exp Immunol 2006;146:303-11.

[36] Pinelli E, Gonzalo RM, Boog CJ, Rutten VP, Gebhard D, del Real $G$, et al. Leishmania infantum- specific $T$ cell lines derived from asymptomatic dogs that lyse infected macrophages in a major histocompatibility complex-restricted manner. Eur J Immunol 1995;25:1594600.

[37] Giunchetti RC, Corrêa-Oliveira R, Martins-Filho OA, Teixeira-Carvalho A, Roatt $\mathrm{BM}$, de Oliveira Aguiar-Soares RD, et al. A killed Leishmania vaccine with sand fly saliva extract and saponin adjuvant displays immunogenicity in dogs. Vaccine 2008;26:623-38.

[38] Fujiwara RT, Vale AM, França da Silva JC, da Costa RT, Quetz Jda S, Martins Filho $\mathrm{OA}$, et al. Immunogenicity in dogs of three recombinant antigens (TSA, LeIF and LmSTI1) potential vaccine candidates for canine visceral leishmaniasis. Vet Res 2005;36:827-38.

[39] Lemesre JL, Holzmuller P, Cavaleyra M, Gonçalves RB, Hottin G, Papierok G. Protection against experimental visceral leishmaniasis infection in dogs immunized with purified excreted secreted antigens of Leishmania infantum promastigotes. Vaccine 2005;23:2825-40.

[40] Lemesre JL, Holzmuller P, Gonçalves RB, Bourdoiseau G, Hugnet C, Cavaleyra $M$, et al. Long-lasting protection against canine visceral leishmaniasis using the LiESAp-MDP vaccine in endemic areas of France: double-blind randomised efficacy field trial. Vaccine 2007;25:4223-34.

[41] Castes M, Agnelli A, Verde O, Rondón AJ. Characterization of the cellular immune response in American cutaneous leishmaniasis. Clin Immuno Immunopathol 1983;27:176-86.

[42] Murray HW. Survival of intracellular pathogens within human mononuclear phagocytes. Semin Hematol 1988;25:101-11.

[43] Iborra S, Abánades DR, Parody N, Carrión J, Risueño RM, Pineda MA, et al. The immunodominant $\mathrm{T}$ helper 2 (Th2) response elicited in BALB/c mice by the Leishmania LiP2a and LiP2b acidic ribosomal proteins cannot be reverted by strong Th1 inducers. Clin Exp Immunol 2007;150:375-85

[44] Pinelli E. Cytokines in canine visceral leishmaniasis. In: Schijns VECJ, Horzinek MC, editors. Cytokines in veterinary medicine (Cap. 14); 1997. p. 21747.

[45] Owens T, Zeine R. The cell biology of T-dependent B cell activation. Biochem Cell Biol 1989;67:481-9.

[46] Pleass RJ, Woof JM. Fc receptors and immunity to parasites. Trends Parasitol 2001;17:545-51.

[47] Ramiro MJ, Zárate JJ, Hanke T, Rodriguez D, Rodriguez JR, Esteban M, et al. Protection in dogs against visceral leishmaniasis caused by Leishmania infantum is achieved by immunization with a heterologous prime-boost regime using DNA and vaccinia recombinant vectors expressing LACK. Vaccine 2003;21:247484.

[48] Reis AB, Teixeira-Carvalho A, Vale AM, Marques MJ, Giunchetti RC, Mayrink W, et al. Isotype patterns of immunoglobulins: hallmarks for clinical status and tissue parasite density in Brazilian dogs naturally infected by Leishmania (Leishmania) chagasi. Vet Immunol Immunopathol 2006;112:102-16.

[49] de Oliveira Mendes C, Paraguai de Souza E, Borja-Cabrera GP, Maria Melo Batista L, Aparecida dos Santos M, Ellner Parra L, et al. IgG1/IgG2 antibody dichotomy in sera of vaccinated or naturally infected dogs with visceral leishmaniosis. Vaccine 2003;21:2589-97. 